\title{
FENOMENA GANGGUAN KESURUPAN \\ (Dalam Perspektif Islam dan Psikologi)
}

\author{
Hermi Pasmawati*
}

\begin{abstract}
Gangguan kesurupan merupakan fenomena yang sudah sangat lazim terjadi di lingkungan kita, namun kejadian ini masih sulit untuk diungkapkan secara ilmiah, masih banyaknya keyakinan bahwa penyebab dari kesurupan pada individu karena pengaruh roh jahat atau kemasukan setan, sehingga metoda pengobatannyapun dilakukan dengan menggunakan mantera-mantera bukan menggunakan doa-doa dari Al-Qur'an, serta yang melakukanya juga paranormal sehingga ada terkesan muatan perilaku syirik di dalamnya, serta kesembuhannyapun bersifat temporal. Untuk itu perlu dibahas bagaimana pandangan menurut Islam dan Psikologi terhadap gangguan kesurupan ini, dari telaah kedua pandangan ini, baik dari segi konsep, proses, dan penyebab kesurupan serta cara mengatasi gangguan kesurupan, ternyata dari kedua pandangan ini memiliki relevansi yang sangat kuat, yaitu kondisi psikologis yang lemah akan sangat mudah dipengaruhi oleh Jin dan bangsanya, serta pengobatan gangguan kesurupan melalui metode terapi ruqyah dalam Islam juga harus diiringi dengan penguatan fungsi psikis dan sepiritul individu yang mengalami kesurupan, sehingga kesembuhan dapat permanen.
\end{abstract}

Kata Kunci : Gangguan Kesurupan, Islam, Psikologi

\section{Pendahuluan}

Gangguan kesurupan bukanlah fenomena yang asing, fenomena ini sering kali terjadi terutama dikalangan pelajar, mahasiswa dan pada perempuan. Akhirakhir ini fenomena gangguan kesurupan kerap terjadi secara massal. Gangguan kesurupan diawali dengan gejala individu yang bersangkutan berteriak histeris, mengalami kejang-kejang, pingsan dan kehilangan kesadaran. Waktu-waktu terjadinya kesurupan pun beragam, untuk kesurupan massal yang cenderung dialami oleh para pelajar, pada umumnya sering terjadi pada saat kondisi akan mengawali atau pada saat jam pelajaran berlangsung, setelah kebersihan bersama, saat menempati ruang kelas baru, sebelum atau saat berlangsungnya proses ujian, pada saat atau setelah apel dan upacara bendera, serta pada saat jam istirahat.Sebagaimana pendapat Andi Hakim yang mengatakan bahwa, kesurupan kerap terjadi pada pelajar, terutama pada saat ujian nasional ataupun ujian sekolah, serta ujian kenaikan kelas. ${ }^{1}$

Fenomena kesurupan tidak hanya terjadi di lembaga-lembaga umum saja, namun di lingkungan pesantren pun kerap terjadi kesurupan baik massal maupun Individu, bahkan pada saat 
mendengarkan lantunan ayat suci AlQur'an pun tidak mustahil fenomena kesurupan terjadi pada individu. Kondisi ini tentu menjelaskan bahwa gangguan kesurupan tidak hanya terjadi pada tempat-tempat yang dianggap mistis saja, namun tempat-tempat yang diyakini telah memberikan kondisi atau pengaruh religi yang tinggipun dapat terjadi fenomena kesurupan. Dalam kepercayaan dan budaya turun temurun fenomena kesurupan masih diyakini sebagai suatu kondisi gangguan prilaku yang disebabkan oleh masuknya semacam makhluk dari golongan Jin atau setan ke dalam tubuh seseorang, sehingga pengobatannya pun masih menggunakan cara-cara mistis, seperti menggunakan bawang putih, jeruk nipis, serta air yang telah diberi mantera-mantera atau dengan cara menekan anggota bagain tubuh yang diyakini tempat masuknya setan seperti ujung ibu jari kaki, ujung ibu jari tangan, kemudian bagian sendi lutut, sendi siku, bagian leher, ubun-ubun. Cara pengobatan ini biasanya juga cukup efektif dalam waktu beberapa menit individu yang mengalami kesurupan langsung sembuh, dan dapat sadar kembali dari prilaku histeris, tidak sadarkan diri atau pingsang, walaupun kondisi energi atau tenaganya masih lemah. Namun jika dilihat dari riwayat sang penderita kesurupan tersebut, kesembuhannya biasanya bersifat temporal atau tidak permanen jika menggunakan berbagai alternatif pengobatan di atas, dan ada kecenderungan untuk kembali mengalami kesurupan.

Dalam kajian ilmu psikologi fenomena kesurupan merupakan salah satu kajian yang cukup menarik untuk didalami, prilaku gangguan kesurupan yang cukup kompleks, dan cukup rumit untuk ditafsirkan dari segi kondisi sadar menuntut analisi yang lebih dalam tentang penyebab, dan bagaimana proses terjadinya gangguan kesurupan tersebut, untuk dapat lebih memahami fenomena kesurupan perlu dijelaskan secara ilmiah, tulisan ini mencoba mendeskripsikan fenomena gangguan kesurupan menurut pandangan Islam dan psikologi, sehingga ada pemahaman baru terkait fenomena gangguan kesurupan dari pandangan Islam dan dari kajian ilmiah (psikologi).

\section{A. Pandangan Islam tentang Gangguan Kesurupan}

Fenomena kesurupan telah terjadi pada zaman Nabi Muhammad SAW, sebagaimana di riwayatkan dalam hadist beriku: 


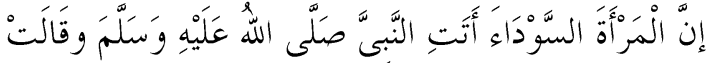

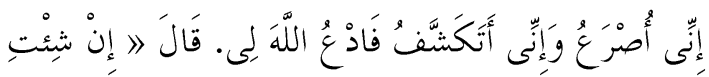

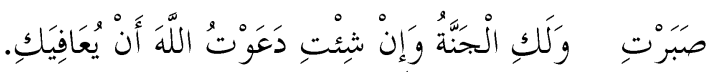

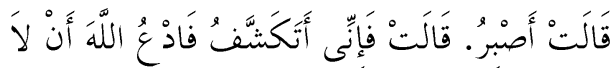
أَتَكَشَنَفَْ. فَدَعَا لَهَا.

Seorang wanita mendatangi Nabi Muhammad SAW, dia mengadukan masalahnya, "Sesungguhnya aku sering kesurupan, hingga auratku terbuka, mohon doakan ya Rasululullah agar aku lekas sembuh."Nabi pun menjawab “ jika kamu bersabar, maka bagimu adalah surga, namun jika engkau tetap berkehendak untuk didoakan, aku akan berdoa pada Allah agar menyembuhkanmu, wanita tersebut berkata'aku memilih untuk bersabar, Namun tolong ya rasulullah untuk mendoakanku agar auratku tidak terbuka, maka Rasulullah pun berdoa untuk wanita tersebut. 2 Dari hadist di atas, dapat kita tafsirkan bahwa anjuran bersabar dapat dimaknai ada permasalahan yang harus diselesaikan dalam diri wanita tersebut, atau dapat juga dimaknai proses penyembuhannya tidak bisa menggunakan cara yang instan.

Dalam bahasa Arab kesurupan berasal dari kata $\mathrm{Al}$ Ash shar 'u yaitu; sejenis gangguan yang dialami oleh seseorang yang diiringi dengan ketegangan pada seluruh anggota tubuh, bahkan tidak jarang menyebabkan pingsan, layaknya penderita epilepsi.3Selanjutnya menurut Ali Muhammad Muthowi,menyebut istilah keseurupan dengan al mass, yaitu jenis penyakit berupa histeria, kesurupan, dan penyakit kejiwaan. Khususnya adalah kekacauan jiwa dan semisalnya, seperti keraguan yang disebabkan gangguan setan jenis jin, tanpa dibedakan pria atau wanita.

Diantara fenomena kesurupan ini adalah kekacauan dalam ucapan, perbuatan dan fikiran.Al Hafidz Ibnu Katsir Rahimahullah dalam Fathul Bary mengatakan kesurupan bisa jadi karena gangguan jin, dan tidak terjadi kecuali dari mereka yang berjiwa kotor; kemungkinan karena baiknya sebagian jenis manusia atau karena menimpakan gangguan kepadanya semata-mata. Dalam surat Al-Baqarah: 275 mengatakan ${ }^{5}$ : Artinya: Orang-orang yang makan riba itu tidaklah berdiri (bangkit dari kuburnya) melainkan seperti berdirinya orang yang kerasukan setan lantaran (tekanan) penyakit gila." (Al-Baqarah: 275).

Ayat di atas dapat ditafsirkan bahwa orang yang kesurupan di dunia, yang mana setan merasukinya hingga menjadi gila atau rusak akalnya.Menurut Ustadz Abu Aqila, aktivis Bengkel Rohani, Dalam 
Al-qur'an surat al Falaq ayat 4 disebutkan soal keberadaan tukang sihir yang mengembuskan kejahatannya pada uqod atau buhul atau simpil atau sarang setan. Nah, pada saat di dalam tubuh ada sarang setan, mereka bisa masuk melalui pembuluh darah karena di situlah letak simpul-simpul setan.Namun, tidak semua pembuluh darah bisa dimasuki setan, kecuali tiga yang sangat sensitif.Rasulullah SAW pernah menyatakan bahwa tiga titik itu adalah pembuluh darah yang menghidupkan potensi otak kecil manusia.Di titik itu, jika kita sering berpikir berlebihan sehingga tidak kuat menahan, hal itu bisa menimbulkan depresi. Ketika terjadi penegangan dalam pembuluh darah kita, maka melemahkan potensi elektro kita sehingga ada arus listrik dari golongan jin masuk dan mempengaruhi sehingga terjadi kesurupan.

Yang kedua, terletak di pembuluh darah yang menghidupkan potensi khayalan.Sama halnya dengan yang pertama, jika itu menegang karena kita terlalu sering mengkhayal maka setan kemungkinan besar bisa masuk.Yang ketiga di pembuluh yang terletak di bawah telinga. Ini bisa menimpa mereka yang malas, kurang kreatif, tidak punya semangat hidup, cemas, dan putus asa, Oleh karena itu kalau kita melihat sejumlah wasiat Nabi, baik yang terekam dalam sunnah ataupun hadis, banyak yang menyuruh kita untuk berdoa agar terlindung dari masuknya setan ke dalam tubuh kita. Setan di sini bisa dalam arti makhluk (material), atau bisa juga dalam arti energi negatif (marah, benci, kufur, stress, kosong, dst.). Sebagai contoh Nabi menyuruh kita membaca ta'awwud ("Aku berlindung dari godaan setan yang terkutuk"). Setiap masuk ke kamar mandi, kita diperintahkan membaca doa. Isinya, minta perlindungan kepada Allah dari setan laki-laki dan setan perempuan. Menurut Al-Ghazali, kamar mandi termasuk tempat favoritnya setan. Kita juga disuruh berpuasa karena dapat mempersempit aliran darah yang dipakai setan untuk masuk ke tubuh kita.

Sedangkan mengenai hal mengapa seorang wanita lebih berpotensi mengalami kesurupan dari pada seorang laki-laki disini dapat dijelaskan bahwa dari dalam surat An-Nisa ayat 34 dikatakan bahwa telah menjadi sunatullah bahwa wanita Allah ciptakan dengan beberapa kekurangan daripada laki-laki, seperti kurang dalam ibadahnya, contoh shalat dalam satu bulan tidak penuh sepertilaki-laki, kurang dari kekuatan fisik dan tenaganya, serta lebih menggunakan perasaan dalam menghadapi suatu permasalahan. 


\section{B. Proses terjadinya kesurupan dalam pandangan Islam}

Berdasarkan telaah dari beberapa ayat ataupun Hadist, dapat disimpulkan bahwa proses terjadinya gangguan kesurupan dalam pandangan Islam pada prinsipnya sejalan dengan proses yang terjadi dalam perspektif psikologi, yang diawali dengan perubahan perilaku secara spontan, tatapan mata tajam, menakutkan, kosong dan lurus kedepan. Disertai juga oleh perubahan suara yang tadinya halus menjadi besar dan berat, berteriak-teriak histeris, disertai gerakan tubuh yang kaku, dan meronta-ronta, suhu badan juga mengalami penurunan. Kekuatan fisik menjadi berubah drastis, terjadi pertambahan tenaga atau energi dari kondisi normal, kadang-kadang bertindak kasar, berlari-lari tidak tentu arah, dan menyakiti orang disekitarnya. Pada saat perubahan kesadaran inilah yang ditafsirkan individu mengalami gangguan Jin.

\section{Faktor penyebab kesurupan dalam pandangan Islam}

Beberapa ayat dan hadist berikut akan menjelaskan bahgamian Islam menjelaskan tentang gangguan kesurupan yang terjadi pada seseorang, yaitu dalam Qur'an surat Al- baqarah :275, “ Orang- orang yang memakan harta riba itu, mereka tidak berdiri (dari kubur mereka) kecuali seperti orang yang kesurupan kemasukan setan"

Sabda Rasulullah SAW:

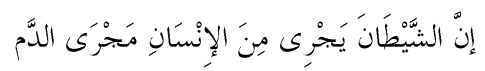

“ Sesungguhnya setan itu berjalan dalam tubuh manusia seperti mengalirnya darah" 5 .

Selanjutnya menurut Imam Ibnu Baththah Rahimakullulah dalm kitab Al- Ibanah: “ Bahwa sesungguhnya setan itu selalu mempengaruhi anak adam sampai akhir hayat nanti, ia berjalan dalma tubuh mereka sepanjang aliran darah, kecuali orang-orang yang dijagaoleh Allah Azawajallah, dari gangguannya. Selanjutnya Islam juga melarang kepada kita untuk menghindari sebab-sebab yang mengundang Jin untuk berbuat jahat pada kita yakni,; Suka melamun, menjauhi sikap-sikap yang berlebihan, terlalu gembira, terlalu bersedih, atau terlalu marah, dana menyimpan dendam. Karena pada kondisi-kondisi yang kurang stabil membuat kita kehilangan kosentrasi, dan memebrikan peluang pada Jin untuk masuk mempengaruhi pikiran dan perasaan kita. Selanjutnya Aldh al-Qarani menjelaskan dalm buku La Tahzan, kesedihan tidak mendatangkan manfaat, bahkan kesedihan merupakan salah satu 
kondisi yang paling disenangi setan, sehingga setan selalu mengarahkan agar umat manusia senntiasa meratapi kesedihanya. 6

Selanjutnya Allah berfirman dalam surat Al-Mujadallah :10;

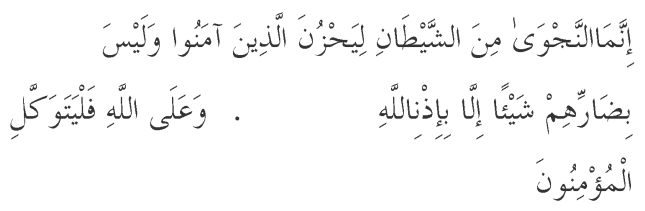

Artinya: "Sesungguhnya pembicaraan rahasia itu adalah dari syaitan, supaya orang-orang yang beriman itu berduka cita, sedang pembicaraan itu tiadalah memberi mudharat sedikitpun kepada mereka, kecuali dengan izin Allah dan kepada Allah-lah hendaknya orang-orang yang beriman bertawakal".

Sejalan dengan surat An- Nhal: 99

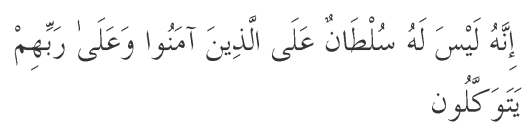

Artinya: Sesungguhnya syaitan itu tidak ada kekuasaannya atas orang-orang yang beriman dan bertawakkal kepada Tuhannya.

Sebagaimana penafsiran M. Quraishab yang menafsirkan bahwa kemampuan setan dalam menjerumuskan dapat diibaratkan sebagai kuman penyakit yang hanya berdampak buruk pada orang-orang yang daya tahan atau sistem imunnya lemah.7 Jika ditinjau dari ilmu medis sistem kekebalan tubuh ini dapat diperoleh dengan cara mejaga kesehiatan dengan olahraga, menjaga pola makan, menerapkan pola hidup sehat, sednagkan sisitem imunitas atau kekebalan rohani dapat diperoleh dengan cara, berserah diri kepada Allah SWT, keikhlasan dan keridhaan serta ketaatan kepada Allah. Orang-orang yang lemah psikologisnya atau rohanynya akan sangat mudah disesatkan oleh setan.

Setan menjerumuskan manusia dengan memanfaatkan potensi dan energi negatif pada manusia yang akan melemahkan kondisi mentalnya menumpulkan pikiran dan perasaannya. Menurut Anwar Sutoyo yang menyebabkan individu mudah digelincirkan setan yaitu: kesedihan diri, yang akhirnya akan mudah untuk dmengikuti bisikan setan. ${ }^{8}$ Dari beberapa penjelasan ayat dan Hadist di atas dapat disimpulkan bahwa pandnagan Islam sangat relevan dengan kajian ilmu psikologi, bahwa faktor-faktor yang menjadi penyebab terjadinya gangguan kesurupan adalah kondisi Rohany yang lemah, yang disebabkan oleh takut yang berlebihan, marah yang tak tertahankan, sedih yang mendalam, kelalaian yang melenakanmemperturutkan nafsu syahwat, dan perilaku manusia yang dapat menyakiti jin, baik disadari oleh 
orang tersebut ataupun tidak. Nah dlam kondisi rohany seseorang yang lemah ini sangat mudah untuk dipengaruhi oleh Jin atau setan.

Beberapa kasus fenomena kesurupan juga terjadi pada orang-orang yang rajin ibadah, atau tergolong religius hal ini disebabkan oleh adanya ketidak singkronan antara pemahaman dengan perilaku ibadah yang dilakukan, keimanan kepada Allah bukan hanya sebatas ucapan saja, namun harus diaplikasikan dalam kehidupan seharihari dengan cara melakukan ibadah yang benar seseuai dengan yang telah dicontohkan oleh Rasullullah serta istiqomah, berserah diri atas ketentuan allah, keikhlasan dalam beribadah, tawakal dalam menerima ketentuan Allah atas dirinya, meninggalkan segala larangan Allah, menjaga lisan, tidak berburuk sangka, atau menjaga diri dari penyakit hati, menjauhi perilaku yang mengarah ke syirik, walaupun sekecil apapun, misalnya melakukan ritual-ritual ibadah yang tidak sesuai dengan sunah Rasul, yang niatnya untuk menambah kekuatan fisik, puasa sepanjang tahun, atau membaca Al-Qur'an dan beribadah di dalam kelambu selama 40 hari dengan maksud dan tujuan untuk memperoleh ilmu hal-hal mistis lainnya.

\section{Cara mengatasi gangguan kesurupan menurut Islam}

Dalam pandangan Islam untuk dapat mengatasi gangguan kesurupan dapat dilakukan dengan terapi Ruqyah syar'iyah, bukan dengan cara membaca mantera-mantera ataupun jampi-jampi yang mengarah kepada perbuatan syirik. Proses terapi Ruqyah menurut Waliyun Arifuddin, sebaiknya ditempuh prosedurprosedur terapi berikut: a) pengenalan ruqyah syar'iyah yang meliputi sumber syariatnya, syarat, dan penanaman nilainilai, b) kontrak pertemuan terapi, sehingga dapat diatur kapan pelaksaan terapi dilakukan, c) pengkondisian tempat dan pasien, d) dialog tentang materi keislaman, e) pembacaan ayat-ayat ruqyah. Jika pasien perlu dibacakan ayatayat ruqyah, maka langkah-langkah yang harus dilakukan adalah sebagaimana yang dijelaskan oleh Majdi Muhammad asy Syahawi sebagai berikut: a) tahap persiapan dengan dua langkah, b) tahap penyembuhan dengan tujuh langkah, c) tahap pasca penyembuhan dengan lima langkah (asy Syahawi, 2001: 101-116). Adapun ramuan yang digunakan adalah: a) habbatus sauda' (jinten hitam), b) kurma 'ajwa, c) madu, d) daun bidara atau sidr, dan e) air (Bari (X/233) dalam Bali, 2001: 175). 
Selanjutnya di samping terapi Rukyah yang dianjurkan di dalam Islam, juga harus diimbangi dengan semangat internal dari pihak yang mengalami gangguan kesurupan untuk memperbaiki ibadahnya dan peningkatan kondisi spiritual yang sesuai dengan sunah Rasulullah SAW, penguatan kondisi psikologis, serta bersikap koopratif dan konsisten dalam menjalani terapi rukyah. Sebagaimana hasil temuan penelitian Zainul Arifin dan Zulkhair, hasil penelitian terhadap tiga orang informen yang menjadi subjek penelitian mengungkapkan bahwa, terapi rukyah akan efektif jika individu yang mengalami gangguan kesurupan dapat koopratif dan konsisten dalam mengikuti saran-saran dari trapsinya, memiliki keinginan atau motivasi yang kuat untuk sembuh, berusaha untuk menguatkan psikologisnya untuk tidak larut dalam masalahnya, peningkatan pola hidup dengan cara memperbaiki kualitas ibadah, adanya dukungan dari orang-orang terdekat untuk kesembuhan individu yang mengalami gangguan kesurupan. ${ }^{9}$

\section{E. Konsep Kesurupan menurut kajian ilmu psikologi}

Dalam kajian ilmu psikologi kesurupan termasuk pada gangguan jiwa ringan (dissociative trance disorder) atau trans disasosiatif. Menurut Prof. Dr.Dadang Hawari psikiater UI, bahwa kesurupan atau possesion adalah reaksi kejiwaan yang dinamakan reaksi desosiasi- yaitu reaksi yang mengakibatkan hilangnya kemampuan seseorang untuk menyadari realitas di sekitarnya itu, yang disebabkan adanya tekanan fisik maupun mental. ${ }^{10}$ Tekanan yang dimaksudkan disini dapat berupa konflik batin atau konflik yang terjadi dalam diri individu tersebut, konflik tersebut lebih banyak ditekan ke alam bawah sadar, tidak diselesaikan dan dikelolah dengan baik, dan akhirnya akan menjadi tumpukan sampah emosi negatif yang menumpuk di alam bawah sadar seseorang, salah satu bentuk kompensasi dari menumpuknya tekanan atau sampah emosi ini adalah dalam bentuk mimpi buruk, mengigau, dan dalam bentuk dissociative trance disorder atau gangguan kesurupan.

Fenomena kesurupan ini dapat terjadi secara individu maupun terjadi secara massal. Kondisi kesurupan massal ini sering menimbulkan persepsi bahwa kesurupan itu dapat menular seperti halnya virus penyakit, namun sebenarnya dalam kajian psikologi kondisi ini terjadi karena adanya histeria massal atau kondisi lingkungan yang saling mempengaruhi sehingga terjadi 
kepanikan secara bersama-sama. Fenomena ini juga dapat menjawab mengapa perempuan lebih cenderung mengalami kesurupan dibanding laki-laki, alasannya adalah karena perempuan lebih mudah dipengaruhi atau sugestble dibanding laki-laki. Selain itu juga perumpuan memiliki kecenderungan lebih besar mengalami stress atau trauma. 11

Selanjutnya dalam sudut pandang hipnosis, kesurupan merupakan proses perpindahan level kesadaran sesorang dari kesadaran normal ke kondisi bawah sadar secara spontan yang disebabkan oleh faktor emosi negatif yang terpendam dan terakumulasi sejak lama, namun luapan emosi tersebut belum pernah dikompensasikan. 11Menurut Maslim, kserupan merupakan gangguan yang menunjukkan adanya kehilangan sementara aspek penghayatan akan identitas diri dan kesadaran terhadap lingkungannya, dalam beberapa kejadian individu tersebut berperilaku seakan-akan dikuasai oleh kepribadian lain, kekuatan ghaib, malaikat atau "kekuatan lain"1

Dari penjelasan di atas dapat disimpulkan bahwa konsep kesurupan menurut pandangan psikologi merupakan kondisi dissosiasi atau hilangnya kemampuan seseorang untuk menyadari realita, tidak mampu mengendalikan dirinya (histria), menampilkan berbagai perilaku yang dimunculkan oleh pribadi yang berbeda (split personality), perpindahan kesadaran dalam level normal ke alam bawah sadar secara spontan, serta dapat menimbulkan efek hitreria massal yang disebabkan oleh sugesti.

\section{F. Proses terjadinya kesurupan menurut} kajian psikologi

Sebagaimana telah dijelaskan sebelumnya dalam pandangan psikologi dissosiasi atau kesurupan merupakan kondisi perubahan level kesadaran seseorang dari kesadaran normal ke kondisi alam bawah sadar secara spontan. Proses terjadinya kesurupan pada umumnya diawali oleh adanya konflik internal atau konflik dalam diri seseorang, yang menyebabkan kondisi kejiwaan dalam keadaan labil, gelisah, dan adanya tekanan. Atau bisa juga disebabkan oleh kondisi dalam diri seseorang yang belum terselesaikan, dan tidak dikompenasaikan atau diekspresikan, serta ditekan di alam bawah sadar, sehingga suatu waktu, tekanan tersebut muncul scara spontan, tidak terkendali dan histeria itulah bagian dari gangguan kesurupan.

Menurut Andri Hakim proses terjadinya kesurupan atau perubahan level kesadaran secara spontan terdiri dari 
tiga bentuk, yaitu;12 1) Induksi secara Visual (Penglihatan), merupakan proses terjadinya kesurupan yang dipicu oleh gambaran, pemandangan, dan lingkungan yang negatif disekitarnya, fenomena kesurupan massal merupakan proses induksi secara Visual yang diawali oleh satu orang yang mengalami kesurupan, karena adanya penumpukan emosi negatif yang meledak secara spontan, selanjutnya fenomena tersebut diikuti oleh yang lain.

Selanjutnya proses terjadinya kesurupan dapat terjadi dengan cara 2) Induksi secara Audio (Pendengaran), merupakan proses terjadinya kesurupan yang dipicu oleh suara, atau bunyibunyian, teriakan histeria yang mensugesti meluapnya emosi negatif seseorang, kondisi ini juga dapat memicu terjadinya kesurupan secara massal, ketika ada seseorang yang memiliki tipe yang sama, mendengar teriakan histeria dari seseorang, atau mendengar sesorang marah-marah, maka secara spontan akan diikuti oleh orang yang memiliki tipe yang sama. 3) Induksi secara Kinestetik (Perasaan) merupakan proses terjadinya kesurupan yang dipicu oleh curahan emosi-emosi negtaf yang terpendam dalm diri seseorang yang diekspresikan dalam bentuk teriakan-teriakan histeria. Kondisi ini menimbulkan perasaan kasihan, empathi terhadap teman yang kesurupan dengan mengikuti perilaku kesurupan yang ditampilkan.

\section{G. Faktor yang menyebabkan terjadinya gangguang kesurupan}

Menurut Sigmund Freud Dissosiasi atau gangguan kesurupan dapat dipicu oleh dorongan-dorongan id tidak tersalurkan karena adanya tekanan, kondisi ini kana menumpuk di bawah sadar seseorang, sehingga kekuatan ego melemah, dissosiasi atau kesedeffence mechaism ego, yang diekspresikan dalam bentuk kehilangan kesadaran atau berkuranya kemmapuan untuk mengingat peristiwa yang terjadi pada dirinya, histeria, dan juga dalam bentuk kehilangan kesadaran atau pingsan. ${ }^{13}$ kesurupan disebabkan oleh faktor-faktor berikut:

1) Predisposisi pembawaan berupa sistem syaraf yang lemah, sensitif.

2) Tekanan-tekanan mental (stres) yang disebabkan oleh kesusahan, kekecewaan, shocks dan pengalamanpengalaman pahit yang menjadi trauma.

3) Disiplin dan kebiasaan hidup yang salah. Hal ini mengakibatkan kontrol pribadi yang kurang baik, atau memunculkan integrasi kepribadian yang sangat rapuh. 
4) Mempergunakan defencemechanism yan $\begin{array}{lr}\text { g negative atau } & \begin{array}{r}\text { keliru } \\ \text { sehingga }\end{array} \\ \text { dan maladjustment, } & \text { banyak } \\ \text { menimbulkan semakin } & \\ \text { kesulitan. } & \end{array}$

5) Kondisi fisik atau organis yang tidak menguntungkan; misalnya sakit, lemah, lelah, fungsi-fungsi organik yang lemah, gangguan pikiran dan badan.

Relevan dengan pedapat di atas, gangguan kesurupan dapat disebabkan oleh kondisi di keluarga yang riqid, hubungan keluarga yang kurang harmonis, didikan orang tua yang terlalu keras, tidak dapat mengekspresikan dan mengungkapakn permasalahanya, tekanan dan stressor yang yang ditekan ke alam bawah sadar, selain itu kondisi suasana ruangan yang pengap, sirkulasi udara terbatas, pencahayaan gelap, pemilihan cat tembok yang gelap, ruangan yang kotor,lantai ruangan yang lembab, serta meja atau kursi yang kotor.

\section{H. Cara mengatasi kesurupan menurut persfektif Psikologi}

Berdasarkan faktor yang menyebabkan sesorang mengalami gangguan kesurupan, maka penangannya pun harus mengacu kepada hal yang menjadi penyebab atau sumber masalah dari kesurupan tersebut, secara umum bahwa penyebab kesurupan disebabkan oleh kondisi psikologis yang lemah, karena perasaan sedih yang berlebihan, kondisi dendam, ataupun tekanan (stres) yang tidak diekspresikan, atau dengan kata lain kondisi energi negatif yang ditekan ke alam bawah sadar, dalam waktu yang lama, untuk mengatasi halhal tersebut dengan cara; meningkatkan kemampuan individu yang mengalami kesurupan dengan cara melatih kemampuan dalam mengolah stres dan konflik dengan cara yang baik. melatih kemapuan meningkatkan toleransi terhadap stres dan tekanan yang dialami, sehingga tidak dikompensasikan dalam bentuk perilaku kesurupan.

Selanjutnya menurut Andri Hakim kesurupan dpat dicegah dan diatasi dengan cara ${ }^{14}$ :

1. Meminimalisisr penyebab drai kesurupan misalnya, mengadakan perbaikan terhadap sisitem pembelajarn yang terkadang menjadi pemicu stres atau tekanan bagi pelajar.

2. Menciptakan lingkungan kademik yang humanis dna menyenangkan.

3. Menciptakan kondisi ruangan fisik yang nyaman, dengan cara mengatur pencahayaan, memilih warna yang cerah dan lembut, serta meningkatkan kebersihan. 
4. Selanjutnya untuk meningkatkan kondsi psikologis individu yang mengalami kesrupan dapat dilakukkan dengan cara melakukkan hipnoteraphy, dengan cara mentrapi individu yang sering mengalami kesurupan dengan melatih kemampuanya lebih terbuka dengan masalah, tekanan atau beban maslah yang dialami, tidak terlalu sensitif, mensugesti untuk dapat lebih tenang, mengurangi kecemasan, serta memberikan penguatan agar individu yang mengalami gangguan kesurupan untuk lebihpercaya bahwa ia mampu menyelesaiakn maslah atau beban yang dialami, memaafkan kondisi masa lalu.

\section{Penutup}

Gangguan kesurupan dalam kedua pandangan di atas, baik secara Islam maupun menurut pandangan psikologis, pada intinya ada kesamaan atau sangat relevan, sebagaimana dijelaskan dalam beberapa ayat dan hadist, kondisi yang paling disenangi oleh jin dan bangsanya adalah kondisi mental atau psikologis manusia yang lemah, kondsi ini sangat mudah dipengaruhi dan dijerumuskan oleh setan atau jin ke arah yang negatif, salah satu kondisi psikologis yang lemah tersebut dijelaskan dalam pandangan psikologi, yaitu, kondisi terlalu sensitif terhadap kondisi kesedihan yang dialami terlalu berlebihan, adanya perasaan stress atau tekanan yang membebani, sehingga tidak dapat berpikir dan bertindak secara rasional, kemudian ketidakmampuan dalam mengolah emosi, sehingga muncul dalam bentuk kompensasi kesurupan, tidak menyadari kondisi dirinya atau seakan-akan muncul kondisi yang terjadi di luar kendali dirinya.

Selanjutnya dalam mencegah atau mengatasi gangguan kesurupan ini, baik dari pandangan Islam maupun dalam pandangan psikologi juga memiliki relevansi yang sangat kuat, sebagaimana hasil penelitian, jika terapi Ruqyah saja dilakukan pada individu yang mengalami gangguan kesurupan, maka kesembuhan individu tersebut sifatnya temporal atau tidak permanen, tanpa diiringi dengan perbaikan atau terapi kondisi psikologis, konsistensi dan koopratif, serta peningkatan kualitas spiritual atau kualitas ibadah individu yang mengalami gangguan kesurupan.

\section{Referensi}

1.Andri Hakim. Hypnosis In Teaching. Jakarta: Visi Media. 2011.hal.159

2.HR. Al-Bukhari 5/2140 (5328) dan Muslim 8/16 (6736).

${ }^{3 .}$ Ad-Dimasyqi, Irfan Bin Salim. Kupas Tuntas Dunia Lain Menyingkap Alam Jin, Menangkal Gangguan Sihir, 
Perdukunan, dan Kesurupan. Solo: AlQowam.2005.hal57.

4.Al- Quran dan Terjemahnya, Khadim alHaramain asy-syarifain-Departemen Agama Republik Indonesia.

5.HR. al-Bukhâri 3/1195 (3107) dan Muslim 7/8 (5808).

6.Aidh al-Qarani. La Tahzan (Jangan Bersedih). (Alih Bahasa Samson Rahman). Jakarta: Qisthi Press.2015.hal 94

7.M.Q. Shihab. Wawasan Al- Qur'an Tafsir Maudhu'I Atas Berbagai Persoalan Umat.Bandung Mihzan.2000.Juz I-XV

8.Anwar Sutoyo. Bimbingan dan Konseling Islam (Teori dan Praktik) Jakarta: Pustaka: Pelajar.2015.hal.275

9.Portalgaruda.Org.article.php.Zainul Arifin dan Zulkhair. Gangguan Kesurupan dan Terapi Rukyah. UIN Maulana Malik Ibrahim.2016.hal.10

10.Maslim, R. 2002. Diagnosis Gangguan Jiwa. PPDGJ-III. hal. 56

11.Andri Hakim. Hypnosis In Teaching. Jakarta: Visi Media. 2011.hal.160

12.Andri Hakim. Hypnosis In Teaching. Jakarta: Visi Media. 2011.hal.161

13.Barlow, D.H. \& Durand, M. 2005. Abnormal Psychology: An Integrative Approach (4th Ed). USA: Thomson Learning. 14.Hakim. Hypnosis In Teaching. Jakarta:

Visi Media. 2011.hal.165-168 